\section{Seedling Development of Sugar Maple and Black Maple Irrigated at Various Frequencies}

\author{
William R. Graves \\ Department of Horticulture, Iowa State University, Ames, IA 50011-1100
}

Additional index words. Acer nigrum, Acer saccharum, drought stress, woody landscape plants

\begin{abstract}
Growth, dry-matter partitioning, and specific mass of lamina of black maple (Acer nigrum Michx.f.) and sugar maple (A. saccharum Marsh.) irrigated at 10-, 26-, and 42-day intervals were compared. Total dry mass, stem length, and surface area of lamina were greater for sugar maple than for black maple for plants irrigated every 10 days. Reducing irrigation frequency curtailed growth of both species, but the reduction was greater for sugar maple than for black maple. The shoot : root ratio was lower for black maple than for sugar maple and was reduced by drought in both species, particularly among plants irrigated every 26 days. Specific mass of lamina increased as plants aged, was greater for black maple than for sugar maple, and decreased in response to irrigation at 42-day intervals. The slower growth, lower shoot : root ratio, and greater specific mass of lamina of black maple indicate this species has a greater capacity to withstand drought than sugar maple.
\end{abstract}

Sugar maple trees are valued for their form, strong wood, and autumn leaf coloration (Dirr, 1990), but leaves of several cultivars are prone to damage from drought stress and wind (Pair, 1991). These problems reduce the usefulness of sugar maple at stressful landscape sites, particularly in the southern and midwestern United States (Dirr, 1990). Black maple has been treated as a subspecies of sugar maple and a separate species (Desmarais, 1952; Dirr, 1990; L.H. Bailey Hortorium, 1976; Ware, 1983). Black maple leaves differ from those of sugar maple: they have three lobes, stipules, pubescence on the abaxial surface, a leathery texture, and a droopy habit (Dirr, 1990; Graves, 1994). Black maple is indigenous farther west in North America than sugar maple; populations are found as far west as Minnesota, Iowa, Kansas, and Arkansas (Dirr, 1990). Its foliar traits and more westerly range have led to speculation that black maple is more resistant to drought and heat stress than sugar maple (Dirr, 1990).

Direct comparisons of black maple and sugar maple growth are limited. Pair (1991) reported that drought caused serious leaf damage on four sugar maple cultivars, including 'Green Mountain', which may be a hybrid of black maple and sugar maple (Dirr, 1990). However, leaf damage was not reported on two black maple selections included in that

Received for publication 15 Feb. 1994. Accepted for publication 2 July 1994. Journal Paper no. J-15736 of the Iowa Agriculture and Home Economics Expt. Station, Ames. Project no. 3229. Technical assistance of J. Dieter and K. Lappegard is gratefully acknowledged. The cost of publishing this paper was defrayed in part by the payment of page charges. Under postal regulations, this paper therefore must be hereby marked advertisement solely to indicate this fact. study. Ware (1983) observed that black maple maintained extensive root growth despite slow shoot growth, and he suggested (personal communication) a low shoot : root ratio permits black maple to avoid foliar stress symptoms during periods of heat and drought. The objective of my study was to compare growth, drymatter partitioning, and specific mass of lamina of black maple and sugar maple seedlings treated with various irrigation frequencies. Specifically, I compared plants grown from seeds collected from three trees of each species in a small portion of their native range. These seed sources were not intended to represent the diversity within these taxa; therefore, the statistical analysis was structured to examine variation in these seedlings specifically, rather than to provide a basis for evaluating broad species differences.

\section{Materials and Methods}

During Sept. and Oct. 1992, samaras were collected from three trees each of black maple and sugar maple. The black maples were in Dolliver Memorial State Park in west-central Iowa (Webster County). Two of the sugar maples were in Backbone State Park in northeastern Iowa (Delaware County). The other sugar maple was in a native woodland in the Minnesota Landscape Arboretum, Chanhassen. Seeds were stratified at $2 \mathrm{C}$ in plastic bags with damp sphagnum moss for 18 weeks and then were sown in flats of Strong-Lite Germination Mix (Strong-Lite, Seneca, Ill.) in Feb. 1993. Flats were held under intermittent mist in a glasshouse and provided 18 -h photoperiods by using incandescent lamps.

On 12 Mar., 140 to 160 seedlings from each of the three sources of both species were transplanted singly into $1840-\mathrm{ml}(15 \times 15 \mathrm{~cm})$, standard plastic pots (Belden Plastics, St. Paul,
Minn.) filled with 1 medium-grade (no. 3) vermiculite : 1 coarse perlite (v/v) (StrongLite). Pieces of plastic screen were placed over drainage holes in the containers to prevent loss of medium during the experiment. Plants were arranged randomly on a glasshouse bench without supplemental irradiance. They were irrigated with a solution of Peters Excel AllPurpose $21 \mathrm{~N}-2.2 \mathrm{P}-16.6 \mathrm{~K}$ and Peters Excel Cal-Mag Special 15N-2.2P-12.5K (GraceSierra, Milpitas, Calif.) at $175 \mathrm{mg}$ N/liter ( $\mathrm{pH}$ 5.2) as needed to keep the surface of the medium moist. This solution was used for all irrigations during the experiment. Of the $\mathrm{N}$ applied, 63\% was from the Cal-Mag Special fertilizer. The rooting medium was $76 \%$ water (by mass) at container capacity.

The 96 most uniform seedlings from each source (576 total) were selected for treatment and randomly arranged on a glasshouse bench on 23 Apr. They were assigned randomly to one of three irrigation regimes (control, moderate drought, and severe drought). Of the 32 seedlings within each of the 18 seed sourceirrigation treatment combinations, eight were assigned randomly to each of three harvest times, either immediately before treatments commenced or after one or two irrigation treatment cycles. The remaining eight seedlings in each group of 32 were selected as indicator plants to determine when to irrigate all seedlings within each treatment combination.

All seedlings were irrigated and allowed to drain for $1 \mathrm{~h}$. The combined mass of the eight indicator pots from each treatment combination was determined. This was repeated each morning of the experiment. Within seed sources, all control seedlings were irrigated when the mass of the indicator pots had decreased by $25 \%$. Likewise, seedlings assigned to moderate drought were irrigated when the mass of indicator pots had decreased by $50 \%$ for the first drought cycle and by $45 \%$ for subsequent cycles. Seedlings in severe drought treatments were irrigated when the mass of the indicator pots had decreased by $58 \%$ for the first drought cycle and by $55 \%$ for subsequent cycles. Preliminary experiments showed that $25 \%, 45 \%, 50 \%, 55 \%$, and $58 \%$ decreases in the mass of indicator pots were associated with reductions of the medium water content (by mass) of $15 \%, 53 \%, 62 \%, 72 \%$, and $77 \%$, respectively. A new initial mass of indicator pots was determined after each group of seedlings was irrigated.

An irrigation cycle was considered complete when all six seed source groups assigned to the severe drought treatment had been irrigated. The second harvest was conducted on 11 June, when the first irrigation cycle ended. The third harvest was conducted on 25 July, when the second cycle ended. The number of irrigations applied from $23 \mathrm{Apr}$. to 25 July to seedlings in control, moderate drought, and severe drought treatments was seven to 11 , three or four, and two, respectively, among seed source groups. The mean interval between irrigations across seed source treatments was 10, 26, and 42 days for control, moderate drought, and severe drought treat- 
ments, respectively. The maximum irradiance at seedling apices during treatments was 400 $\mu \mathrm{mol} \cdot \mathrm{s}^{-1} \cdot \mathrm{m}^{-2}$, and air temperature ranged from 18 to $32 \mathrm{C}$.

Stem length was measured at each harvest. Lamina surface area was determined with an area meter (model 3100; LI-COR, Lincoln, Neb.). Roots were washed in tap water to remove medium. Dry mass of lamina, roots (defined as all tissues below cotyledon scars), and stems (including petioles) were determined separately after desiccation at $67 \mathrm{C}$ for 2 days. Specific mass of lamina was determined by dividing lamina mass by surface area. The data were analyzed by using an analysis of variance appropriate for a completely randomized design with six treatments and 24 replications per treatment. The treatments were regarded as a factorial combination of two species and three irrigation levels. Eight of the 24 seedlings in each replication came from each of three sources. The variation among sources within species was not examined. Therefore, tests of significance between species are intended to compare seedlings from the particular seed sources used, rather than being representative of broad species differences. Means comparison tests were made using the least significant difference (LSD) at $P$ $\leq 0.05$ (Steel and Torrie, 1980).

\section{Results}

For the first harvest, there were no differences between seedlings assigned to the different irrigation treatments, so data were combined (Table 1). Mean shoot dry mass of sugar maple was $44 \%$ greater than that of black maple when treatments began, but there was no difference in mean root dry mass of the two species. Mean shoot : root ratio of sugar maple was 35\% higher than that of black maple. Mean lamina surface area of sugar maple was $74 \%$ larger, and the specific mass of lamina was $22 \%$ less than for black maple. Mean stem length of the two species differed by $2 \mathrm{~mm}$ (Table 1).

Irrigation interval effects on all variables, except specific leaf mass, were similar at the

Table 1. Characteristics of black maple and sugar maple seedlings harvested 23 Apr., the day irrigation treatments began. Data from plants assigned to different irrigation regimes were combined. Values are means of 72 replicates.

\begin{tabular}{|c|c|c|c|}
\hline \multirow[b]{2}{*}{ Characteristics } & \multicolumn{2}{|c|}{ Species } & \multirow[b]{2}{*}{$\mathrm{LSD}_{0.05}$} \\
\hline & $\begin{array}{l}\text { Black } \\
\text { maple }\end{array}$ & $\begin{array}{l}\text { Sugar } \\
\text { maple }\end{array}$ & \\
\hline $\begin{array}{l}\text { Shoot dry } \\
\text { mass (mg) }\end{array}$ & 209 & 300 & 24 \\
\hline $\begin{array}{l}\text { Root dry } \\
\text { mass (mg) }\end{array}$ & 115 & 123 & 12 \\
\hline $\begin{array}{l}\text { Shoot : root } \\
\text { mass ratio }\end{array}$ & 1.85 & 2.49 & 0.16 \\
\hline $\begin{array}{l}\text { Lamina surface } \\
\text { area }\left(\mathrm{cm}^{2}\right)\end{array}$ & 50 & 87 & 8 \\
\hline $\begin{array}{l}\text { Specific mass of } \\
\text { lamina }\left(\mathrm{mg} \cdot \mathrm{cm}^{-2}\right)\end{array}$ & 3.67 & 3.02 & 0.17 \\
\hline Stem length (mm) & 36 & 34 & 2 \\
\hline
\end{tabular}

second and third harvests, so data from only the third harvest are presented for these variables. The species $\times$ irrigation frequency interaction was significant for total dry mass $(P>$ $\mathrm{F}=0.0013)$, stem length $(P>\mathrm{F}=0.0085)$, and lamina surface area $(P>\mathrm{F}=0.0029)$. These interactions are explained by comparing the means for the two species at the 10-and 26-day irrigation intervals (Fig. 1). Mean total dry mass, stem length, and lamina surface area of sugar maple were more than double those of black maple for plants irrigated every 10 days (Fig. 1), and the species differed in magnitude of growth reduction caused by less frequent irrigation. For example, mean dry mass of sugar and black maple irrigated at 26-day intervals was $56 \%$ and $43 \%$ less, respectively, than for plants irrigated every 10 days (Fig. 1A). Compared to plants irrigated most frequently, irrigation at 26-day intervals reduced mean stem length of sugar maple by $63 \%$, whereas the irrigation interval did not affect stem length of black maple (Fig 1B). Lamina surface area of sugar maple was larger than that of black maple only among plants irrigated at 10-day intervals (Fig. 1C). Species ( $P$ $>\mathrm{F}=0.0039)$ and irrigation frequency $(P>\mathrm{F}$ $=0.0001)$ affected the shoot $:$ root ratio, and there was no interaction between these factors. The mean shoot : root ratios for black maple and sugar maple across irrigation frequencies were 0.67 and 0.85 , respectively $(\mathrm{LSD}=0.12$ ). Averaged over species, irrigation at 10-, 26-, and 42-day intervals resulted in mean shoot: root ratios of $0.93,0.56$, and 0.77 , respectively $(\mathrm{LSD}=0.15)$

Specific mass of lamina increased during the experiment for both species. At the second harvest, black maple and sugar maple lamina had specific masses of 4.86 and $4.60 \mathrm{mg} \cdot \mathrm{cm}^{-3}$, respectively $(\mathrm{LSD}=0.21)$, and there were no irrigation regime or interaction effects. Spe-
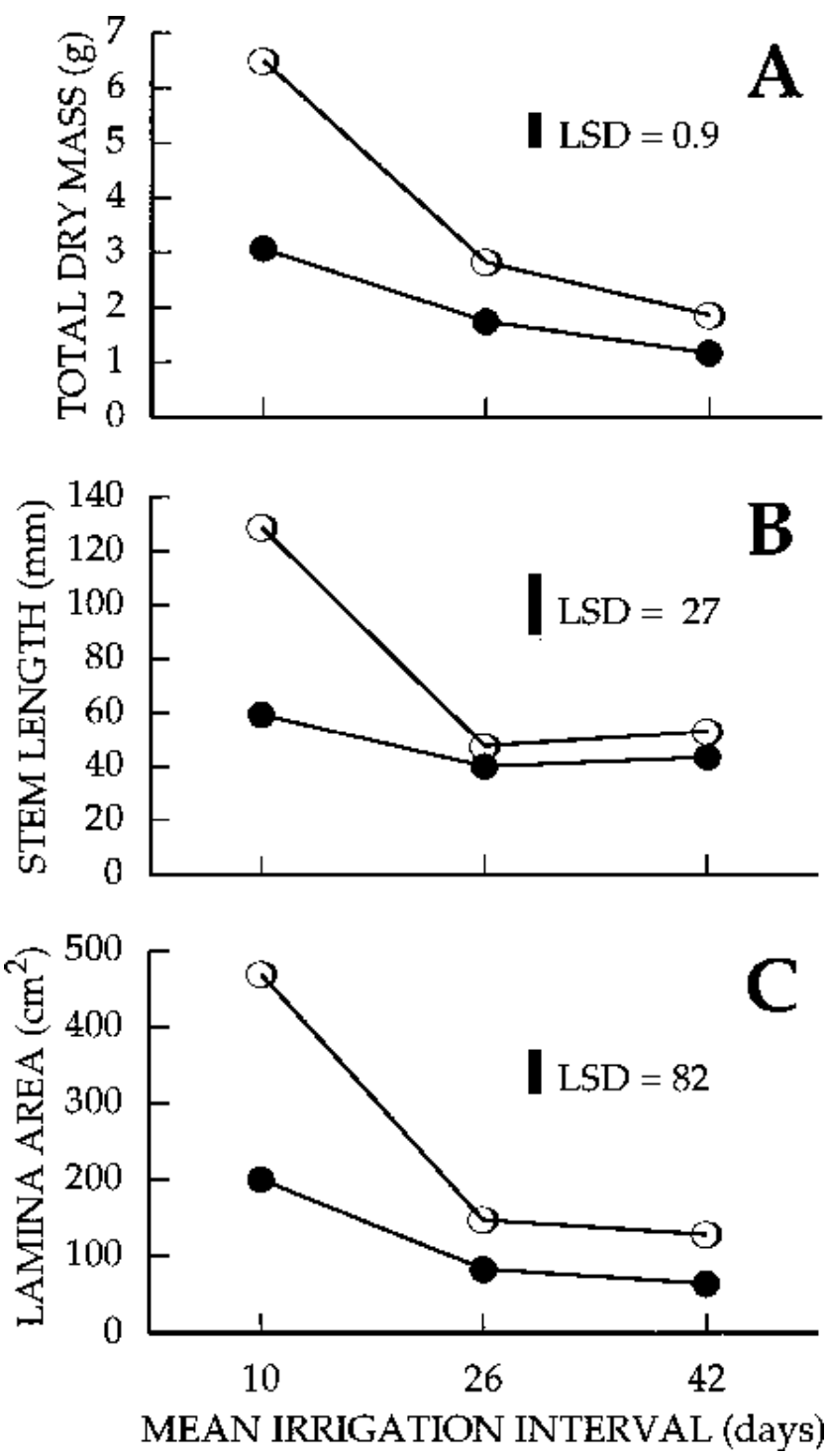

Fig. 1. (A) Total dry matter, (B) stem length, and (C) lamina surface area of (-- ---) black maple and (--O--) sugar maple seedlings treated for 93 days with various irrigation intervals; these intervals represent the control, moderate drought, and severe drought treatments described in the text. Values are means of 24 replicate seedlings, eight grown from seed collected from each of three trees. LSD values are at $P \leq 0.05$. 
cies $(P>\mathrm{F}=0.0001)$ and irrigation frequency $(P>\mathrm{F}=0.0001)$ affected specific mass of lamina at the third harvest, and there was no interaction. The mean specific mass of lamina for black maple and sugar maple across irrigation frequencies was 5.81 and $5.35 \mathrm{mg} \cdot \mathrm{cm}^{-2}$, respectively $(\mathrm{LSD}=0.19)$. Averaged over species, irrigation at 10-, 26-, and 42-day intervals resulted in mean specific mass of lamina of $5.62,5.84$, and $5.28 \mathrm{mg} \cdot \mathrm{cm}^{-2}$, respectively (LSD $=0.23$ ).

\section{Discussion}

These results are consistent with previous speculation (Dirr, 1990; Ware, 1983) that black maple has a greater capacity to withstand drought than sugar maple. The impact of drought on dry mass, stem length, and lamina area was more pronounced for sugar maple than for black maple (Fig. 1), and black maple grew more slowly than sugar maple when irrigated frequently (Table 1, Fig. 1). If these trends continue throughout ontogeny, the quantity of water needed to sustain a tree of acceptable quality in the landscape might be lower for black maple than for sugar maple.

The relatively low shoot : root ratio of black maple confirms an earlier field observation (Ware, 1983) and suggests that this species maintains more root surface area per unit leaf surface than sugar maple. Further research should address this possibility. Low shoot : root ratios are associated with drought stress avoidance in other woody species (Graves and Wilkins, 1991; Joly et al., 1989), but differences in the partitioning of dry matter between shoots and roots are not necessarily consistent with ratios of absorptive and transpiring surfaces (Rieger and Duemmel, 1992). There is no obvious explanation for the lower shoot : root ratio of plants irrigated every 26 days than for those irrigated every 42 days. Most plants irrigated every 42 days wilted between irrigations, whereas leaves of plants irrigated every 26 days remained turgid. The stress severity caused by irrigation at 42 -day intervals may have constrained alterations in the shoot : root ratio. Additional studies should relate drymatter partitioning with irrigation frequency and plant water status in these species.

The specific mass data indicate that the leaf blades of black maple are thicker or have more densely arranged cells than those of sugar maple. This finding is consistent with field observations indicating that black maple leaves have a leathery texture (Graves, 1994). Thick leaves (Abrams, 1988; Donselman and Flint, 1982) and high specific mass of leaves (Abrams et al., 1990; Joly et al., 1989; Rieger and Duemmel, 1992) are characteristic of plants from xeric habitats and may represent adaptations for sustaining a relatively high water-use efficiency (Nobel, 1980) and photosynthetic capacity per unit leaf surface area (Pearce et al., 1969; Rieger and Duemmel, 1992). Yet Ledig and Korbobo (1983) found photosynthesis per unit leaf weight was correlated negatively with specific leaf mass in sugar maple from different altitudes in New Hampshire. The ecological significance of the relatively high specific mass of lamina of black maple warrants further research. There was no effect of irrigation interval on specific mass of lamina until the final harvest, when plants irrigated at 42-day intervals showed a reduction. The explanation for this decrease is unclear, but changes in the cuticle, vascular tissue, starch content, and cell count and size could have been responsible (Nobel, 1980).

My study provides a comparison of plant development in black maple and sugar maple grown under well-irrigated conditions and with stress induced by drought. The differences in biomass production, surface area, and specific mass of lamina between these black maples and sugar maples indicate that further investigations designed to characterize species differences by using a larger and more representative array of seed sources are warranted. Additional work also is needed to determine whether the data that I reported for seedlings are consistent with the drought resistance of mature plants under landscape conditions. Black maple may merit more frequent use at stressful landscape sites where the ornamental qualities of hard maples are desired. Leaves of black maple turn yellow to orange in autumn (Graves, 1994), and the overall landscape value of black maple is considered equal to that of sugar maple (Dirr, 1990). Tree producers, however, might consider the relatively slow growth rate of black maple to be a disadvantage.

\section{Literature Cited}

Abrams, M.D. 1988. Genetic variation in leaf morphology and plant and tissue water relations during drought in Cercis canadensis J. For. Sci. 34:200-207.

Abrams, M.D., M.E. Kubiske, and K.C. Steiner. 1990. Drought adaptations and responses in five genotypes of Fraxinus pennsylvanica Marsh.: Photosynthesis, water relations and leaf morphology. Tree Physiol. 6:305-315.

Desmarais, Y. 1952. Dynamics of leaf variations in the sugar maples. Brittonia 7:347-388.

Dirr, M.A. 1990. Manual of woody landscape plants: Their identification, ornamental characteristics, culture, propagation, and uses. 4th ed. Stipes, Champaign, Ill.

Donselman, H.M. and H.L. Flint. 1982. Genecology of eastern redbud (Cercis canadensis). Ecology 63:962-971.

Graves, W.R. 1994. Acer saccharum subsp. nigrum. Amer. Nurseryman 179(6):130.

Graves, W.R. and L.C. Wilkins. 1991. Growth of honey locust seedlings during high root-zone temperature and osmotic stress. HortScience 26:1312-1315

Joly, R.J., W.T. Adams, and S.G. Stafford. 1989. Phenological and morphological responses of mesic and dry site sources of coastal Douglas-fir to water deficit. For. Sci. 35:987-1005.

L.H. Bailey Hortorium. 1976. Hortus III. Macmillan, New York.

Ledig, F.T. and D.R. Korbobo. 1983. Adaptation of sugar maple populations along altitudinal gradients: Photosynthesis, respiration, and specific leaf weight. Amer. J. Bot. 70:256-265.

Nobel, P.S. 1980. Leaf anatomy and water use efficiency, p. 43-55. In: N.C. Turner and P.J. Kramer (eds.). Adaptation of plants to water and high temperature stress. Wiley, New York.

Pair, J.C. 1991. Growth, fall color development, leaf scorch, and xylem water potential of sugar maples under stress. HortScience 26:746. (Abstr.)

Pearce, R.B., G.E. Carlson, D.K. Barnes, R.H. Hart, and C.H. Hanson. 1969. Specific leaf weight and photosynthesis in alfalfa. Crop Sci. 9:423426.

Rieger, M. and M.J. Duemmel. 1992. Comparison of drought resistance among Prunus species from divergent habitats. Tree Physiol. 11:369380.

Steel, R.G.D. and J.H. Torrie. 1980. Principles and procedures of statistics. 2nd ed. McGraw-Hill, New York.

Ware, G.H. 1983. Acer saccharum subspecies nigrum: Meritorious midwestern maple. Metropolitan Tree Improvement Alliance 4:1-6. 